\title{
A bélmikrobiom szerepe az alkoholos és nem alkoholos zsírmáj kialakulásában, progressziójában
}

| Bán Orsolya' ${ }^{1}$ Lisziewicz Julianna dr., Nyúl Dóra, ${ }^{1,3}$, Peták István dr.2 ${ }^{2}$ Tordai Attila dr. ${ }^{3}$, Baffy György dr. ${ }^{4}$, Schwab Richárd dr. ${ }^{1}$

${ }^{1}$ MIND Klinika Kft.; ${ }^{2}$ Oncompass Medicine Zrt.; ${ }^{3}$ Semmelweis Egyetem, Kórélettani Intézet, Budapest; ${ }^{4}$ VA Boston Healthcare System, Harvard Medical School, Boston, MA, USA

Correspondence: mailbox@schwab.hu

A nem alkoholos zsírmáj járványszerű terjedése nem független az elhízás és metabolikus betegségek elmúlt évtizedekben tapasztalt szomorú térhódításától a fejlett világban. A mikrobiomkutatás új távlatokat nyitott a patomechanizmus megértésében és a progresszióval fenyegető formák felismerésében. Ebben kulcsszerepet játszik a bélflóra összetételének és funkciójának változásával járó gyulladás és az intesztinális barrier sérülése, amelyek célzott helyreállítása hozzájárulhat a betegség sikeres kezeléséhez és a progresszió megelőzéséhez. Érdekes módon, hasonló mechanizmusok vezérlik az alkoholos májkárosodás patogenezisét és a két betegségspektrum a korábbi elképzelésekkel ellentétben egy kontinuumot alkot. A betegség tünetei helyett a gondozási gyakorlat célja tehát az oki tényezők korrekciója: mindennek egyik fő eleme a célzott táplálásterápia, amelyben a fizikai aktivitás és egyéb életmódtényezőkön túl specifikus probiotikumok használata is szerepet kaphat. További klinikai vizsgálatok szükségesek a rutin klinikai gyakorlat számára pontos irányelvek meghatározásához.

KULCSSZAVAK: kulcsszavak: mikrobiom, NAFLD, nem-alkoholos-zsirmáj, bél-barrier, endotoxin, transzlokáció, táplálásterápia, probiotikumok

\section{The role of gut microbiome in the pathogenesis and progression of alcoholic and non-alcoholic fatty liver disease}

The epidemic of fatty liver disease is closely linked to the rapidly growing prevalence of obesity and associated metabolic disorders. In contrast to earlier concepts, alcoholic and non-alcoholic fatty liver disease significantly overlap, share many features, and may be viewed as a spectrum of disease. Recent studies of the gut microbiome not only improve our understanding of the pathogenesis but also lead to early recognition of progressive forms of fatty liver disease. Alterations of the gut microbiome associated with inflammatory changes and damage of the intestinal barrier, represent novel targets for both treatment and prevention strategies. Medical interventions should focus on eliminating causative factors rather than treating symptoms of disease. This objective can be achieved by using nutrition therapy, lifestyle modifications and targeted probiotics. Future clinical trials evaluating these approaches may facilitate the development of specific treatment guidelines.

KEYWORDS: microbiome, NAFLD, non-alcoholic fatty liver, intestinal barrier, PAMP, translocation, nutrition therapy, probiotics 


\section{A bélmikrobiom}

A genomika korszaka előtt a mikrobiológia elsősorban az invazív tulajdonságú „patogén” baktériumok azonosítására törekedett és ehhez szelektív táptalajokon, a normál flórától idegen kórokozók kimutatása volt az elsődleges cél. A „normál” flóra rutinszerű vizsgálata épp sokszínűsége miatt metodikai korlátokba ütközött. Ennek megfelelően nagyon kevés ismeretünk volt bizonyos „idiopátiás” kórállapotok, gyulladásos folyamatok, valamint a metabolikus betegségek és a különböző testtájakon élő mikrobák öszszetételének változása közötti kapcsolatról.

A nagy hatékonyságú szekvenálási eljárások megjelenésével új időszak kezdődött, ami a humán genom projekt (HGP) (1), illetve a daganat genom projekt (CGP) (2) tapasztalatai és tanulságai nyomán az emberi test különböző felületein (úm. bél, bőr, vagina, pénisz, fül, orr, szem) célozta meg a "velünk élő" mikrobák genetikai állományának feltérképezését, és ezek rendszertani szempontok alapján történő azonosítását, sokaságuk (fajgazdagság) és számarányuk meghatározását egészséges önkénteseken. Az első eredmények több száz ember vizsgálata alapján, egy összefoglaló tanulmányban jelentek meg 2012-ben (3). Ennek a jelentősége nem csupán egy online bővülő statisztikai sokaság létrejötte, ami összehasonlíthatóvá tette az egészségesnek vélt populáció egy mintáját a különböző betegcsoportok adataival, hanem egy konszenzusos metodikai platformot is validált (4), ami jól reprodukálható és egymással összehasonlítható módszertani útmutatást is adott a következő tanulmányok készítői számára. Nagy előnye a területnek, hogy a mintavétel nem invazív és könnyen ismételhető módon történik, ugyanakkor a metodika a bakteriális genom sajátosságánál fogva a korábbi, emberen végzett hasonló nagy deskriptív genetikai kutatások (HGP, CGP) költségeinél lényegesen szerényebb erőforrásokból megoldható.

A baktériumok azonosítása a riboszomális RNS-t kódoló DNS-szakaszok 16S szakaszának vizsgálatával történik, amely két evolúciósan konzervált régióval rendelkezik és lehetővé teszi standard primer párok alkalmazását gyakorlatilag bármely baktérium rendszertani csoport egyedi azonosítására a nemzetségszintig (5). A két primer pár közötti szakasz ugyanis kellően variábilis ahhoz, hogy a törzs, osztály, rend, család, nemzetség klasszifikáció biztonsággal elvégezhető legyen. Ez nem teszi lehetővé az egyes baktériumfajok és alfajok egyedi azonosítását (ami kétségkívül a módszer gyengesége), ugyanakkor elsősorban nem is egyes fajok azonosítása a cél, hiszen az egyes betegségasszociációk feltáró szűrése és statisztikai elemzése után a későbbiekben sokkal kisebb elemszámon, homogénebb csoportok között van lehetőség mélyebb szekvenciaanalízisek lefuttatására, ami a mikrobiológiában korábban megszokott diagnosztikus pontosságot elérhetővé tehet.

Az új nomenklatúra szerint „mikrobiom” meghatározásnak hívjuk az emberi testnedvekből kimutatható, nem emberi DNS-szakaszok összességét. A mikrobiom fajgazdagságának meghatározására ugyanakkor bevezetésre került az ún. operatív taxonómiai egység (Operative Ta- xonomic Unit, OTU) (6), ami egy adott nemzetség genetikai határvonalát az ebben sorolt egyedek riboszómáinak 16S RNS-szakaszát kódoló DNS 97\%-os egyezése nyomán húzta meg. Ennek a rögzítésére pragmatikus okokból volt szükség, ugyanis a vizsgálatok rengeteg, korábban tenyésztéssel soha nem azonosított, így ismeretlen biológiai viselkedésű baktériumot mutattak ki, amelyek esetében a tulajdonságok és fajjellegek elválása, valamint a patogenitási szerep egyelőre bizonytalan. Az OTU ugyanakkor lehetővé teszi konszenzus alapján, a „genus" rendszertani egységek specifikus elkülönítésén túlmenően, egy objektív fajgazdagság-paraméter azonosítását (7), illetve ennek összehasonlítását egyedi minták, vagy betegkohortok adataival. Épp ezért problémás olyan mikrobiomtesztek értékelése, amelyek fajspecifikus primerek alkalmazásával a fenotípus alapján „ismert” baktériumok meghatározásán alapulnak, mert ez a módszer a nemzetközi adatbázisok „mértékegység-rendszerével” nem összehasonlítható eredményeket szolgáltat.

Számos mikroorganizmus, köztük eukarióták, archaea, baktériumok és vírusok kolonizálják a gyomor-bélrendszert. A bélben található mikrobák többsége baktérium, körülbelül $10^{14}$ baktériumsejt (8). Az egészséges bélben a Firmicutes (nagyrészt Gram-pozitív) és Bacteroidetes (nagyrészt Gram-negítv) baktérium törzsek dominálnak és kis arányban találhatók aktinobaktériumok, proteobaktériumok és verrucomicrobia törzsbe tartozók (9). A bél mikrobiómja egy dinamikus ökoszisztéma, amely a korhoz, a földrajzi elhelyezkedéshez, az étrendhez és a környezeti tényezőkhöz kapcsolódik. Ezért nehéz az egészséges bélmikrobiom stabil összetételének azonosítása.

\section{Bélbarrier-károsodás és mikrobiális transzlokáció}

A bélbarrier-struktúrákról alkotott ismereteink exponenciálisan bővültek a mikrobiomkutatás előtérbe kerülésével. A klasszikus leírások alapján az intesztinális epitheliális barrier definíciója egy egyrétegű hámsejtsor és az azt rögzítő struktúrák egysége, ami passzív védelmet nyújt a külvilággal szemben, illetve aktív transzportmechanizmusokkal szabályozni tudja az adott bélszakaszra specifikus abszorpciós/szekréciós múködést. Ennek megfelelően a bélbarrier „külvilággal” szembeni védelem tekintetében egy passzív védőfal, aminek "fizikai" sérülései vezetnek a megváltozott intesztinális permeábilitáshoz.

A barrierkárosodás kérdése elsődlegesen súlyos betegségek szövődményeként került előtérbe (pl. akut pancreatitis). Hazai munkacsoportoknak döntő szerepe volt abban, hogy a korai enterális táplálás bevezetésével, a főként iatrogén koplalással összefüggő endotoxémia és gyulladásprogresszió a klinikai gyakorlatban is felismerésre került és megelőzhetővé vált (10).

A bélbarrier-károsodás átmeneti formái jól ismertek fertőző betegségek esetén is, amikor a víz- és ionvesztés különböző ismert mechanizmusai vezetnek a barrier összeomlásához és sokktünetekhez (11). Akut, ismert etiológiájú betegség esetén ezek elhárítása viszonylag egyszerű oki gyógymódot, illetve kiegészítő szupportív kezelést igé- 
nyelt, mivel az akut noxa megszűnése után a bél-barrier spontán regenerálódott, és így a barrierműködés mélyebb szabályozása és ennek zavarai kisebb figyelmet kaptak.

A bélbarrier-károsodás tekintetében a gyulladásos bélbetegségek (Inflammatory Bowel Disease, IBD) egy különlegesen izgalmas csoportot képviselnek (12). Heterogén etiopatogenezissel jellemezhető betegségcsoportról beszélünk, de az intesztinális permeabilitás növekedése ennek gyakorlatilag minden formájában megfigyelhető. Bizonyos esetekben ez örökletes hajlamhoz is köthető (ilyen pl. a családokban halmozódó colitis ulcerosa, illetve coeliakia) (13), illetve valószínúleg a Crohn-betegség egyes (ma még nem így, a genetikai ok-okozat alapján klasszifikált) formái jelentik a betegségspektrum másik végét, amit NOD2-mutáció jellemez (14). Utóbbi esetben a veleszületett immunitás olyan funkciózavara áll az autoimmun folyamat hátterében, ami a normál intesztinális permeabilitás mellett is képes fokozott gyulladásos választ generálni a bakteriális endotoxinok barrieren átjutó formáinak hatására. Ennek oka ebben az esetben ugyanis a fiziológiás negatív feed-back szabályozás defektusa, amit az antigénprezentáló sejtek „Toll-like” receptorain (TLR) keresztül induló gyulladásos válasz intracelluláris kontrolljának hibája okoz. A kontrollálatlan immunválasz jellegzetesen magával vonja az intesztinális permeabilitás másodlagos növekedését. A gyulladást ezután már fenntartja a gyulladás nyomán sérült barrier miatt kialakuló endotoxaemia, ami a bélfal teljes szélességét érinti, és amit elsősorban a folyamatosan aktiválódó TLR-jelátvitel nyomán felszabaduló TNF-alfa közvetít. Nem meglepő módon a TNF-gátló kezelésre a Crohn-betegség súlyosabb klinikai formáiban a NOD-2 mutáns betegek (jellegzetesen a terminális ile- umot érintő, fisztulázó esetek) jól reagálnak és ennek a kezelésformának a klinikai bevezetését elsősorban ez az indikáció uralta (15).

Meg kell említeni ugyanakkor a paracelluláris transzlokáció (16) és (17) jelenségét is, ami a fentiekhez képest sokkal később került leírásra, és szerepe még ma is intenzív kutatás tárgya. Itt a barrier áteresztőképességének aktív szabályozásáról beszélhetünk, ami az ún. M-sejtek tevékenységéhez köthető (18). Ezek a sejtek a barrier külső felszínét „monitorozva” szabályozottan juttatnak „molekuláris információt "immunrendszerünk számára a bélfórát alkotó és a bélhám bolyhain élő baktérium, gomba, archea fajok sokaságáról, és ezt az információt a barrieren szabályozottan átjuttatva, lehetővé teszik a regionális nyirokcsomókban a specifikus mikrobiális antigének prezentációját. A szervezetünk ezzel mintegy felkészül egy majdani esetleges barriersérülés esetére, amikor a luminális mikrobák invázióját kell majd megakadályozni. Ugyanakkor a bélflórát alkotó mikrobák antigén-homogenitása effektív barriersérülés nélkül is gyulladásos előaktivációt eredményezhet, ami a mai tudásunk szerint a perifériás vérben is mérhető CRP (normáltartományon belül) 0,1-5 mg/l értékek közötti emelkedésével mutat egyenes arányosságot (19).

A mikrobiom összetétele, az azt alkotó fajok antigénstruktúrájának gyulladásos reaktivitása, az antigén-prezentáló sejtek molekuláris jelátviteli apparátusának zavarai, illetve a barrier (szabályozott vagy aspecifikus) permeabilitásának fokozódása mind része annak a mai tudásunk szerinti többváltozós egyenletnek, ami az IBD kialakulásáért felelős, és amelyek eredője a klinikai megjelenési formát és a betegség kimenetelét is meghatározza (1.ábra).

\section{1. ábra: A mikrobiota, a barrier és a TLR-jelátvitel zavarainak kapcsolata a bélgyulladások különbözö klinikai formáinak kialakításában}

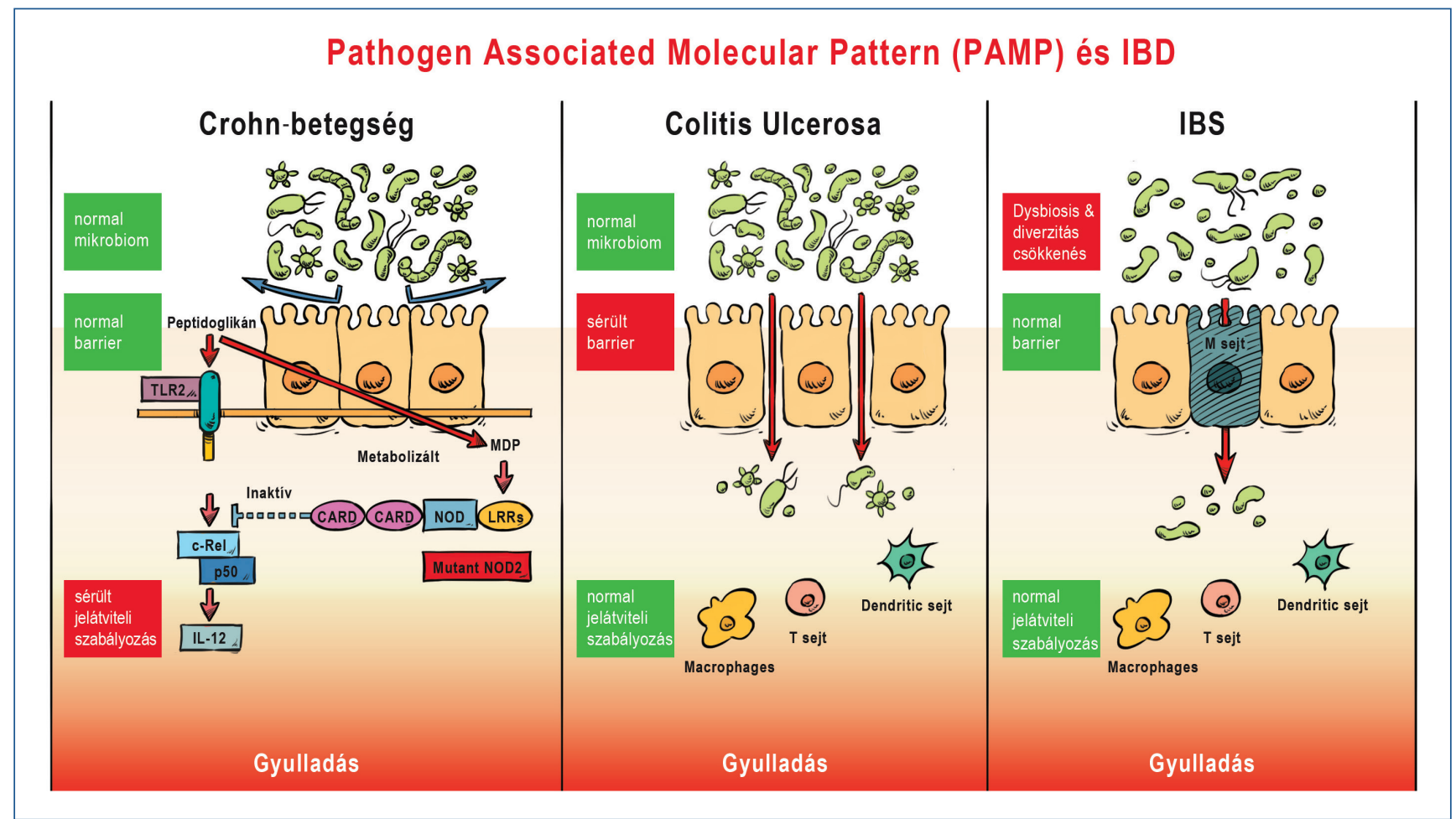




\section{A bélmikrobiom és a májkárosodás kapcsolata}

A zsírmáj a metabolikus betegségek gyakori szervspecifikus megjelenési formája. A gyakorló gasztroenterológus ultrahang-praxisában az elhízott betegek kb. 30-50\%-ában megtalálható ez a morfológiai entitás (20). Talán mert a steatosis előfordulása mindennapos, a gyakorlatban sem pontos klasszifikációja, sem szisztematikus gondozása nem része a rutin orvosi gyakorlatnak. Az elhízás és az ezzel gyakran társuló metabolikus és kardiovaszkuláris szövődmények prevalenciájának növekedése miatt általános jelenség, hogy a kóros klinikai-laboratóriumi paraméterek elfogadottnak tekintett határai egyre inkább eltolódnak és mind a betegek, mind az ellátó orvosok motivációja csökken a kórjelző tünetek észlelésekor az okok felderítésére. Ugyanakkor azt is tudjuk, hogy az esetek kb. 25\%-ában a steatosis gyulladással társul, és a zsírmájbetegség nem alkoholos steatohepatitis (NASH) kórformájának progressziója nem sokban különbözik az alkoholos májkárosodástól (21). Ennek egyik eredője az a statisztikákat is torzító gyakorlat, hogy a már cirrózisba progrediáló formák esetében a szociálisan elfogadott mértékű alkoholfogyasztással a kórelőzményben a beteg progresszív májbetegségét végül „egyéni érzékenység" alapon alkoholeredetűnek tekintik. Rosszabb esetben a beteget stigmatizálva zugivónak minősítik.

A humán mikrobiom-projekt publikálása (22) óta eltelt évek kutatásai ezt ugyanakkor új megvilágításba helyezik.
A nem alkoholos májkárosodás (Non-Alcoholic Fatty Liver Disease, NAFLD) a bélmikrobiom változásának az a formája, amikor a gazdaszervezet anyagcseréjét a bakteriális rövid szénláncú zsírsav metabolitjai jellegzetesen „átprogramozzák". Ennek pontos patomechanizmusa még nem minden részletében ismert, de központi szerepet játszik benne az izomszövetben kialakult inzulinrezisztencia és következményes hyperinsulinaemia. Az inzulin-jelátvitel sérülésének több oka is lehet, de több egymástól független, a jelenséget más oldaláról vizsgáló tanulmány is központi szerepet tulajdonít a bakteriális propionát béllumenen belül felszaporodott mennyiségének, illetve a butirát/propionát index csökkenésének (23). Ez egyrészt közvetlen összefüggést mutatott az epidemiológiai vizsgálatok alapján a 2-es típusú cukorbetegség (T2DM) előfordulásával (24), másrészt sikerült igazolni, hogy az imidazol-propionát intracelluláris receptormechanizmusán keresztül aktiválni tudja az mTORfehérjét, ami az inzulinreceptor-szubsztrát gátlása révén $a z$ inzulin-jelátvitelt blokkolja (25) (2. ábra).

Ez a mechanizmus magyarázhatja a metformin kedvező hatását a mikrobiomhoz köthető inzulinrezisztencia reverziójában, ami a hyperinsulinaemia oki kezelését jelenti. Saját munkacsoportunk előzetes eredményei alapján a bélflóra változása az első lépést jelenti a hyperinsulinaemia - inzulin rezisztencia - T2DM úton, ahol a metformin bevezetése nemcsak az anyagcserehelyzetet javította, de a kórképet fenntartó mikrobiom-változásra is kedvező hatással volt (26).

\section{2. ábra: A bakteriális propionát/butirát arány és az energiamérleg kapcsolata: az mTOR-kináz aktiválás inzulinrezisztenciához vezet}

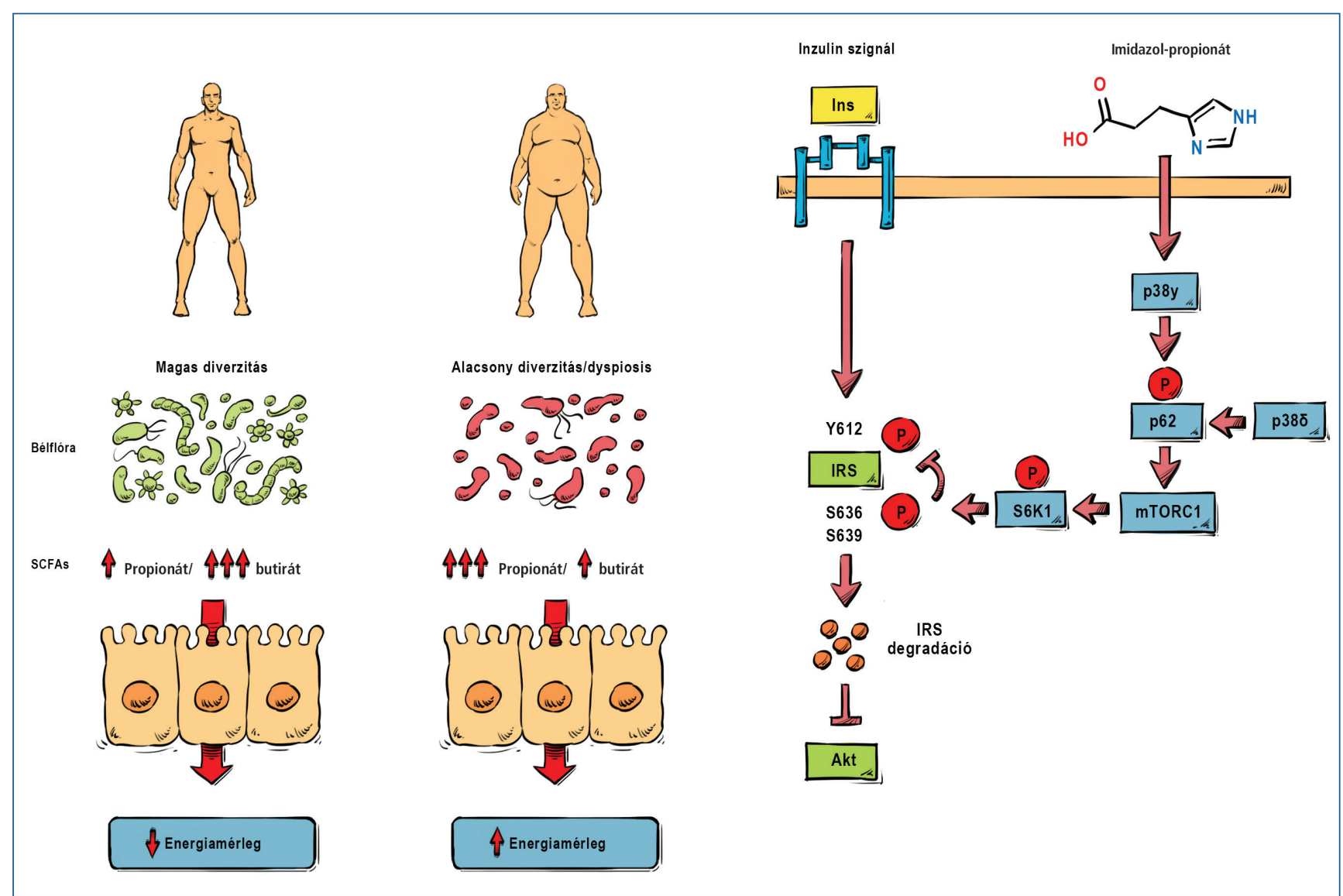


Mai tudásunk szerint ugyanakkor a máj gyulladásos elváltozásaiban a fentiektől független mechanizmusok is szerepet játszanak, mint például a bélbarrier sérülése révén a portális keringésbe jutó, immunológiailag aktív bakteriális degradációs termékek (Pathogen Associated Molecular Patterns, PAMP). Mindezen antigének mennyisége és jellege, valamint a gazdaszervezet HLA-rendszere és immunológiai reaktivitása meghatározza az immunválasz erősségét és következményeit. Ez utóbbi két tényező egymástól elválaszthatatlannak látszik. Adott antigénstruktúrák (baktériumok) bizonyos HLA-típusok esetében okoznak különösen agresszív reaktivitást, és a staging nehézségét épp az adja, hogy a portális keringésbe kerülő PAMP-struktúráknak nem elég az abszolút értékét ismernünk, hanem ezt össze kell vetni és valószínúleg együtt kell értékelni a beteg HLA genetikájával is (27).

\section{Táplálásterápia májbetegeknek}

A múltban rengeteg félreértés és káros gyakorlat jellemezte a májbetegek táplálásterápiáját. Ennek középpontjában az ureaciklus, a bevitt táplálékfehérjék metabolizmusa és a májkárosodás révén a vérben megjelenő hyperammonaemia, valamint ennek klinikai manifesztációja állt (28).

Ennek egyik forrása, hogy a Child-IV. stádiumú cirrotikus betegek klinikumának középpontjában a varixvérzéshez kapcsolódó, és a bélrendszerbe jutó vérzés nyomán típusosan megjelenő, mélyülő hepaticus encephalopathia állt. Ennek (29) klinikai javulását pl. laktulóz alkalmazásával javítani lehet (30), ami ahhoz a téves következtetéshez is vezetett, hogy az egyszerübb cukrok bevezetése és a magas fehérjetartalmú béltartalom „kimosása”, a fehérje „terhelés” mérséklése kedvező hatású.

Ismert volt ugyanakkor, hogy az alkoholos májbetegek elégtelen minőségű és mennyiségű táplálkozása szoros összefüggést mutat magas mortalitásukkal és a táplálkozás helyreállítása mind a morbiditási, mind a mortalitási adatokat kedvezően befolyásolja (31). A magasabb fehérjetartalmú mesterséges enterális táplálás nemhogy rontotta, hanem statisztikailag szignifikánsan javította a hepaticus encephalopathia objektív értékeit, amit jól lehet monitorozni olyan vizsgálatokkal, mint a számkapcsolási teszt vagy a hepaticus encephalopathiás index (32).

A PAMP-transzlokáció és az ehhez kapcsolódó, a máj sinusoidokban megjelenő, fibrózisba is progrediáló gyulladásos válasz ismeretében a táplálásterápia célja egyértelműen definiálható. Egyrészt a bélmikrobiomot alkotó baktériumok összetételét kell módosítanunk úgy, hogy a kórosan magas intesztinális permeabilitás mellett a keringésbe jutó bakteriális bomlástermékeinek arányát kevésbé reaktív irányba toljuk el. Klinikai vizsgálati evidenciák alapján ez a stratégia nemcsak elméletben müködik: a specifikus probiotikum-készítmények protektív hatása elsősorban nem a barrierregeneráción keresztül volt igazolható, hanem a kevésbé reaktív PAMP-ok révén a gyulladásos aktivitás enyhült előrehaladott alkoholindukált cirrózisban (33). További klinikai vizsgálatokat igényel annak a tisztázása, hogy pl. a korábban IBS-nek klasszifikált, de helyesebben gyulladásos dysbiosisnak nevezhető esetek- ben, amikor a barrierkárosodás is összefügg a kórosan átalakult intesztinális flórával, a dysbiosis korrekciója fogja-e javítani a barrierfunkciót is. Az alkoholindukált májbetegségben a barriersérülés oka ugyanis maga az alkohol, amit elsősorban a védőnyák helyreállítása befolyásolhat, ahogy azt a fehérjedús tápszerekkel történő kiegészítő enterális táplálás során igazoltuk (34).

A barrier-regenerációhoz jelen gyakorlatunkban ezért magas fehérjatartalmú tápszereket használunk. A különösen súlyos barrierkárosodás esetén, amikor a beteg vezető tünetei között különböző ételallergiák bőr- és ízületi manifesztációi is fennállnak, akkor saját tapasztalatunk alapján mindezt tejmentes tápszerek formájában szükséges alkalmazni. A komplex barrierregeneráció (prebiotikum, probiotikum, tápszer és életmód-tényezők korrekciója) révén mindez azonban olyan mértékben javulhat, hogy a tejtartalmú tápszerek bevezetése 3 hónapon belül általában sikeres. Ennek eredményeképpen aztán egyszerü bioorganikus, jó minőségű élelmiszerekből válogatott rostdús diétával, prebiotikumok és tápszerek nélkül a páciens egyensúlyban tartható és tünetmentes lesz. Ismét csak saját gyakorlatunkban a barrierregenerációban is hatékony probiotikum (35) hosszú távú alkalmazását annak függvényében ajánljuk, hogy a mikrobiom-diverzitás sérülése milyen mértékű. Középsúlyosnál nagyobb diverzitás-csökkenés esetében (amit a vizsgálat betegpopuláció 50 -es percentilis értékéhez igazított cut-off paraméternél határoztunk meg), a tartós probiotikumalkalmazás tűnik biztonságosnak. Az átmeneti barriersérüléssel járó állapotok, mint az akut stressz, kisebb mennyiségú alkoholfogyasztás, kialvatlanság, interkurrens betegség (pl. influenza) esetében ugyanis a tünetek heves relapszusa jellemzően előfordul, ami a páciens életminőségét és az életmód-terápia iránti elkötelezettségét is jelentősen befolyásolja. A probiotikum-védelem ugyanakkor ezekben az esetekben úgy múködik, mint egy biztonsági öv, ami ezt megakadályozhatja egészen addig, amíg a mikrobiom diverzitása helyre nem áll. A diverzitás fokozására hatékony táplálásterápia pontos formái jelenleg is kidolgozás alatt vannak és ezek részletes ismertetése meghaladja a jelen tanulmány kereteit. A legsúlyosabb esetekre kell rezerválni a széklet-transzplantációt. Ez gyakorlatilag életmentő lehet, ami a súlyos Clostridium Difficile fertőzéseknél jól ismert (36), ugyanakkor nem tudjuk megfelelően szűrni a donorokat, pl. vírusokra, ami az alkalmazás kockázatait a rutinszerű hepatitis és HIV-szűrés előtti érában végzett vértranszfúzióhoz teszi hasonlóvá, aminek a szövődményei már kezdenek előtérbe kerülni (37).

\section{Megbeszélés}

A zsírmáj az eddigi klinikai gyakorlatnál nagyobb figyelmet igényel. Nem elegendő a vírusok és autoimmun markerek, illetve az alkoholos etiológia kizárása alapján a NAFLD-diagnózissal megnyugodva a beteg életmódjával azonosítva a problémát sablonos fogyásra buzdítani. Különösen a transzamináz-emelkedéssel járó formában, a probléma klinikai súlyossága és patomechanizmusa is azonos az alkoholos májbetegség progressziójával. Annak megfe- 
lelően, ahogy az alkohol problémáival szembesítünk egy alkoholos zsírmájban (ALD) szenvedő pácienst és felhívjuk a figyelmét a cirrózis progresszív jellegére, valamint potenciálisan visszafordíthatatlan természetére, az alkoholos és nem alkoholos zsírmáj esetében is ugyanúgy kell eljárnunk. Explorálni kell az ide vezető táplálkozási és életmódtényezőket, illetve szükség szerint saját gyakorlatunkban ezt gyógyszeresen is támogatjuk. A folyamat hátterében, sok esetben klinikailag inzulinrezisztencia áll, amikor is az életmód és diétás váltás mellett adekvát dózisú metformin felépítése sokat segíthet a páciens számára az életmódváltáshoz vezető úton és korábban sikerélményt ad. A metformin mai tudásunk és a korábban bemutatottak szerint az mTOR-gátláson keresztül oki módon befolyásolja az inzulinrezisztenciát és állítja helyre az inzulinreceptor intracelluláris szignált. Ráadásul vannak arra vonatkozó adatok, hogy a metformin magát a bélfóra-eltolódást is kedvezően befolyásolja (38), amit saját megfigyelésünk is alátámasztott inzulinrezisztencia, hyperinsulinaemia és metforminnal kezelt kettestípusú cukorbetegeken (39). Vannak arra vonatkozó tapasztalatok, hogy az epesav-készítmények (pl. ursodeoxycholsav) ezekben a betegekben ugyanúgy csökkenteni tudják a transzamináz-emelkedést, ami a gyulladásos aktivitás közvetlen markere (40). Alkalmazásuk azonban itt egyenlőre off-label kezelésnek számít és a specifikus indikációs területektől eltérően hazánkban kiemelt biztosítói támogatásra nem jogosít.

Fontos ugyanakkor tudatosítani a betegekben, hogy a zsírmájjal együtt járó és akár transzamináz-emelkedéssel is jellemezhető májkárosodás oka nem a túlsúly. Az elhízás a bélflóraváltozással együtt járó inzulinrezisztencia miatt alakul ki. A májkárosodás ugyanakkor annak a következménye, hogy a bélbarrier-sérülés miatt a bélflórából származó bakteriális degradátumok (PAMP struktúrák) a sinusoid keringésbe jutnak, és ott a Kupffer-sejteket aktiválva gyulladásos károsodást okoznak. A zsírmáj, a túlsúly és a transzaminázok emelkedése ezért nem feltétlenül van egymással szoros arányban.

Döntő fontosságú epidemiológiai adatokból tudjuk, hogy a NAFLD stádiumai egymásba folyamatos átmenetet képeznek és az alkoholindukált májbetegséghez hasonlóan cirrózisba tudnak progrediálni. Gondozásba vételkor épp ezért döntő, hogy anamnesztikusan felderítsük az etiológiai faktorokat és a beteg számára egyértelműsítsük a kockázatokat, ami fontos a diétahibák és az alkohol, illetve egyéb életmódtényezők szerepének tisztázása szempontjából. Saját gyakorlatunkban ezen felül a stádiummeghatározásnak része a fibroscan vizsgálat is, hiszen a kezdeti fibrotikus elváltozások morfológiai azonosítása és a magas rizikójú betegek időszakos monitorozása másképp nem lehetséges (41).

Az életmód- és táplálásterápia felépítése és követése sokat hangsúlyozott interdiszciplináris összefogást igényel. Ebben az orvosi szakterületeken túl elsősorban dietetikusok, mozgásterápiás szakemberek szerepe kiemelt, továbbá nyilvánvalóan a társszakmák összefogása szükséges, hiszen sok esetben idősebb, polimorbid betegekről van szó, akik a cukorbetegségen túlmenően, jellemzően hipertónia és annak kardiovaszkuláris és egyéb szövődményeivel is rendelkezhetnek, így a napi szintű mozgás és sport beiktatása nagy figyelmet, tapasztalatot és előzetes kockázatfelmérést igényel. Ugyanez igaz szemészeti, az ízületek, mozgásszervek, valamint a pulmonológiai és alvásdiagnosztikai területekre is. A sikeres életmódváltás ugyanakkor megváltoztatja az egész betegségspektrum természetét és teljes egészében revezibilis lehet. Saját gyakorlatunkban rengeteg beteg hagyja el az antihipertenzív és antidiabetikus kezelésének döntő többségét, és 8-10 féle gyógyszeres kezelésből 1 év után 1-2, inkább csak a hosszú távú kockázatokat csökkenteni képes készítmények maradnak, egy teljes egészében megújult életminőséggel.

\section{Köszönetnyilvánítás}

A közlemény az Eureka16-1-2017-0002 kutatási projekt támogatása mellett jött létre

\section{Etikai közzétételek}

Dr. Schwab is founder of DiaVitas, a lifestyle program targeting microbiome based solution of metabolic and inflammatory disorders. Dr. Schwab and Dr. Petak are founders of Oncompass Medicine active in the field of molecular diagnostics-based precision medicine.

\section{Irodalom}

1. Human Microbiome Project Consortium. Structure, function and diversity of the healthy human microbiome. Nature 2012; 486(7402): 207-14. Published 2012 Jun 13, doi.org/10.1038/nature11234

2. Cancer Genome Atlas Research Network, Weinstein JN, Collisson EA Mills GB, Shaw KR, Ozenberger BA, Ellrott K, Shmulevich I, Sander C Stuart JM. The Cancer Genome Atlas Pan-Cancer analysis project. Na Genet 2013; 45(10): 1113-20. doi.org/10.1038/ng.2764

3. Gonzaga-Jauregui C, Lupski JR, Gibbs RA. Human genome sequencing in health and disease. Annu Rev Med 2012; 63: 35-61. doi. org/10.1146/annurev-med- 051010-162644

4. Vassy JL, Lautenbach DM, McLaughlin HM, Lautenbach DM, McLaughlin HM, Kong SW, Christensen KD, Krier J, Kohane IS, Feuerman LZ, Blumenthal-Barby J, Roberts JS, Lehmann LS, Ho CY, Ubel PA, MacRae CA Seidman CE, Murray MF, McGuire AL, Rehm HL, Green RC. The MedSeq Project: a randomized trial of integrating whole genome sequencing into clinical medicine. Trials 2014; 15: 85. doi.org/10.1186/1745-6215-15-85 5. Rooks MG, Garrett WS. Gut microbiota, metabolites and host immunity Nat Rev Immunol 2016; 16(6): 341-52. doi.org/10.1038/nri.2016.42

6. Pace NR, Stahl DA, Lane DJ, Olsen GJ. Analyzing natural microbial populations by rRNA sequences. ASM News 1985; 51: 4-12.

7. Stackebrandt E, Goebel BM. Taxonomic Note: A Place for DNA-DNA Reassociation and 16S rRNA Sequence Analysis in the Present Species Definition in Bacteriology. Int J Syst Evol Microbiol 1994; 44: 846-849. doi. org/10.1099/00207713-44-4-846

8. Sekirov I, Russell SL, Antunes LC, Finlay BB. Gut microbiota in health and disease. Physiol Rev 2010; 90: 859-904. doi.org/10.1152/physrev.00045.2009

9. Eckburg PB, Bik EM, Bernstein CN, Purdom E, Dethlefsen L, Sargent M, Gill SR, Nelson KE, Relman DA. Diversity of the human intestinal microbial flora. Science 2005; 308: 1635-1638. doi.org/10.1126/science. 1110591

10. Hamvas J, Schwab R, Pap A. Jejunal feeding in necrotising acute pancreatitis-a retrospective study. Acta Chir Hung 1999; 38(2): 177-85.

11. Berkes J, Viswanathan VK, Savkovic SD, Hecht G. Intestinal epithelial responses to enteric pathogens: effects on the tight junction barrier, ion transport, and inflammation. Gut 2003; 52: 439-51. doi.org/10.1136/ gut.52.3.439

12. Michielan A, D'Incà R. Intestinal Permeability in Inflammatory Bowel Disease: Pathogenesis, Clinical Evaluation, and Therapy of Leaky Gut. Mediators Inflamm 2015; 2015: 628157. doi: 10.1155/2015/628157 doi. org/10.1155/2015/628157

További irodalom megtalálható a szerkesztőségben, valamin

a www.gastronews.olo.hu weboldalon. 